\title{
4-5 Yaş Çocuklarının Yaralanma Riski Davranışlarının Cinsiyet, Yaralanma Tipi ve Bağlamı Açısından Incelenmesi
}

\author{
Özlem Yurt ${ }^{1} \oplus$, Sadiye Keleş²®
}

'Trabzon Üniversitesi, Fatih Eğitim Fakültesi Temel Eğitim Bölümü Okul Öncesi Eğitimi Anabilim Dalı, Trabzon, Türkiye

'Zonguldak Bülent Ecevit Üniversitesi, Ereğli Eğitim Fakültesi Temel Eğitim Bölümü Okul Öncesi Eğitimi Anabilim Dalı, Zonguldak, Türkiye

Özlem Yurt, Dr. Öğr. Üyesi

Sadiye Keleş, Dr. Öğr. Üyesi

Bu araştırma 5. Uluslararası Okul Öncesi Eğitimi Kongresi'nde (18-21 Ekim 2017) sözlü bildiri olarak sunulmuştur.

Iletişim:

Dr. Öğr. Üyesi, Özlem Yurt

Trabzon Üniversitesi, Fatih Eğitim Fakültesi

Temel Eğitim Bölümü Okul Öncesi Eğitimi

Anabilim Dalı, Trabzon, Türkiye

Tel: +904623777261

E-Posta: 0zlemyurt37@gmail.com
ÖZET

Amaç: İstemsiz yaralanmalar, tarih boyunca insan yaşamını ve yaşam kalitesini tehdit eden unsurlardan biri olmuştur. Gelişimsel dönemler açısından incelendiğinde, yaralanmaların en sık çocukluk döneminde yaşandığı bilinmektedir. Bu doğrultuda araştırmanın amac। 4-5 yaş çocuklarııın yaralanma riski davranışlarııın cinsiyet, yaralanma tipi ve yaralanma bağlamı açısından incelenmesidir.

Yöntem: Çalışma iki bölümden oluşmaktadır. Çalışma 1'de çocukların yaralanma riski davranışlarını belirlemek için 493 çocuğun annesi ile Yaralanma Davranışı Kontrol Listesi'nin geçerlik ve güvenirlik çalışması yapıImıştı. Gerçekleştirilen DFA bulgularına göre "Yaralanma Davranışı Kontrol Listesi'nin geçerli ve güvenilir bir ölçme yaptı̆ı̆ saptanmıştır. Çalışma 2 ise, iki aşamadan oluşmaktadır; ilk aşamada çocuklar ile birebir görüş̧me yapılarak çocuklara "Yaralanmış bir ç̧cuk çizer misin?" yönergesi verilip çizimlerinin bitmesinin ardından bazı sorular sorulmuş, ikinci aşamada ise çocukların annelerine Yaralanma Davranışı Kontrol Listesi verilmiştir. Çalışma 2'ye kolay ulaşabilir durum örneklemesi ile yaşları 43-65 ay aralığında 98 çocuk ve anneleri katılıııstır. Tüm anneler araştırmaya gönüllü olarak dahil olmuş̧ur. Çocukların 49'u kız, 49'u ise erkek çocuktur. Veri toplama amaciyla, anneler tarafından doldurulan Yaralanma Davranıı̧ı Kontrol Listesi kullanıımıştır. Veriler faktöriyel varyans analizi ile analiz edilmiștir.

Bulgular: Sonuç olarak, cinsiyet ve yaralanma bağlamı, çocukların yaralanma riski davranışlarında anlamlı fark yarattığı, bunun yanı sıra cinsiyet ve yaralanma tipi etkileşiminin çocukların yaralanma riski davranışlarında istatistiksel olarak anlamlı fark oluşturduğu saptanmıştır.

Sonuç: Bir diğer ifade ile çocukların cinsiyeti ve yaralanma bağlamı tek başlarına çocukların yaralanma riski davranışları üzerinde farkllaşmaya neden olurken, yaralanmanın tipi ve çocuğun cinsiyeti, birlikte, çocukların yaralanma riski davranışları üzerinde farklılaşmaya neden olmaktadir.

Anahtar sözcükler: Okul öncesi dönem, yaralanma riski davranışı, yaralanma tip yaralanma bağlamı, cinsiyet

\section{A STUDY OF 4-5 YEAR-OLDS' INJURY-RISK BEHAVIOURS IN TERMS OF GENDER, INJURY TYPE AND CONTEXT}

\section{ABSTRACT}

Objectives: Throughout history, unintentional injuries have posed a threat to human life and the quality of life. In the context of developmental phases, injuries are known to occur mostly in childhood. In the light of this, the present study aims to consider 4-5 yearold children's injury-risk behaviours in terms of gender, injury type, and context.

Methods: The study is composed of two parts. In Study 1, the Injury Behaviour Control Checklist was tested for validity and reliability with the mothers of 493 children in order to identify injury-risk behaviours. CFA findings suggest that the Injury Behaviour Control Checklist' can produce a valid and reliable assessment. Study 2 had two steps. In the first step, one-to-one interviews were conducted with the children, who were requested to 'draw an injured child' and were subsequently asked some questions after their drawings had been completed. In the second step, the children's mothers were given the Injury Behaviour Control Checklist. A total of 98 children between 43 and 65 months of age and their mothers took part in Study 2. Selection was by convenience case sampling, All of the mothers participated in the study voluntarily. 49 of the children were female and 49 were male. For data collection, the Injury Behaviour Control Checklist completed by the mothers was used. The data was analysed through factorial variance analysis.

Results: The study concludes that gender and the context of injury cause a significant difference in children's injury-risk behaviours. In addition, the interaction between gender and the type of injury causes a statistically significant difference in children's injury-risk behaviours.

Conclusion: While the children's gender and the context of injury can each separately modify children's injury-risk behaviours, the type of injury and the children's gender can only modify the risk when both are taken into account.

Keywords: Pre-school period, injury-risk behaviour, injury type, injury context, gender
Gönderilme Tarihi : 16 Şubat 2018

Revizyon Tarihi : 05 Nisan 2018

Kabul Tarihi : 11 Nisan 2018 
stemsiz yaralanmalar, tarih boyunca insan yaşamını ve yaşam kalitesini tehdit eden unsurlardan biri olmuştur. Gelişimsel dönemler açısından incelendiğinde, yaralanmaların en sık çocukluk döneminde yaşandığı görülmektedir. Yaralanmaların bir kısmı çocuk ölümleri ile sonuçlanırken bir kısmı da günlük yaşam kalitesinin düşmesine neden olmaktadır. Günümüzde gelişmiş ülkelerde olduğu gibi gelişmekte olan ülkeler açısından da çocuk yaralanmaları önemli bir sorundur. Avrupa'da ölümcül istemsiz yaralanmalara neden olan başlıca yaralanmalar trafik kazaları, boğulma, zehirlenmeler, yanma ve düşmelerdir. Türkiye'de ise (Grafik 1) 2013-2014 yıllarında çocuk ölümlerinin nedenleri incelendiğinde, 1-14 yaş arasındaki çocukların ölüm nedenleri arasında, dışsal yaralanma ve zehirlenmeler olduğu tespit edilmiştir (1). Bu noktada, yaralanmaya bağlı çocuk ölümlerinin önlenmesinde çocuklarda yaralanma riski içeren davranışların analiz edilmesi ve bu davranışlarla ilişkili olan faktörlerin tespit edilmesi, uygulanacak önleme programları açısından değer kazanmaktadır.

Çocukların yaralanma riski davranışlarında etkili olan ve bu davranışlarla birliktelik gösteren çeşitli faktörler saptanmıştır. Bunları (a) çocuğa ilişkin özelikler (b) aileye ilişkin özellikler ve (c) yaralanma riski bağlamı olarak sınıflandırmak mümkündür. Çocuğa ilişkin özellikler çerçevesinden bakıldığında; yaş (2), cinsiyet (2), toplumsal cinsiyet rolü (3), yaralanma geçmişi, mizaç $(4,5)$, hiperaktivite (6) ve algının çocukların yaralanma davranışları üzerinde fark yarattığı bilinmektedir. Aileye ilişkin özellikler çerçevesinden bakıldığında ise; aile büyüklüğünün (2), kardeş sayısının (2) ve büyük kardeşin varlığının $(7,8)$ çocukların yaralanma davranışları üzerinde fark yarattığı kanıtlanmıştır.
Yaralanmalar, ayrıca, gerçekleştiği bağlamlar ve türleri açısından çeşitlilik göstermektedir. Bağlamsal açıdan irdelendiğinde, yaralanmaya neden olan kazaların büyük bir kısmının ev ortamında yaşandığı $(9,10)$ ve ilk 6 yaşa kadar yaralanan bölgenin sıklıkla dirsek bölgesi olduğu (9) bilinmektedir. Türleri açısından incelendiğinde ise çocukların en sık düşme-kayma tipi kazalar geçirdikleri $(11,12,13,14,15,16,17)$, düşmeyi ise yanma ve delici-kesici aletlerle yaralanmaların izlediği $(16,17,18)$ saptanmıştır.

Bu bilgiler ışığında çocukluk çağındaki yaralanmaların önüne geçilmesi için geniş kapsamlı ve etkili önleme programları geliştirilmiş ve test edilmiştir (19). Bu programların büyük bir çoğunluğunun ebeveynlere yönelik $(20,21)$ olduğu bilinmektedir. Ebeveynler, çeşitli şekillerde çocukların yaralanma riski davranışlarını yönetebilirler; rehberlik sunabilir, bu davranışlara yönelik süpervizyon (gözetim ve denetim) sağlayabilir ya da bu davranışlara tamamen müdahale edebilirler. Elbette çocukların risk alma davranışları, çocuk yaralanmalarının önemli belirleyicileri arasında yer almaktadır (4). Bu nedenle "ilgili davranışın sonuçları hakkında kesinlik olmayan tüm davranışlar" (22) olarak tanımlanan risk alma davranışlarını incelerken, bu davranışların gelişim ve öğrenmeye olumlu katkısı göz ardı edilmemelidir. Bu noktada güvenlik ve çocuklara risk alma davranışlarını yönetme fırsatı sunma arasındaki dengenin sağlanması önemlidir. Ebeveynler, güvenlik ve macera arayışını dengelemek ve çocuklarına günlük risk ve belirsizlikleri yönetme olanakları sunma konusunda çeşitli farklııklara sahiplerdir: Bazı ebeveynler yaşam becerilerini geliştirmek için çocuklarının yaşlarına uygun risk alma etkinliklerine katılımlarını teşvik ederken, nispeten risksiz yaşayan ebeveynler, çocuklarının

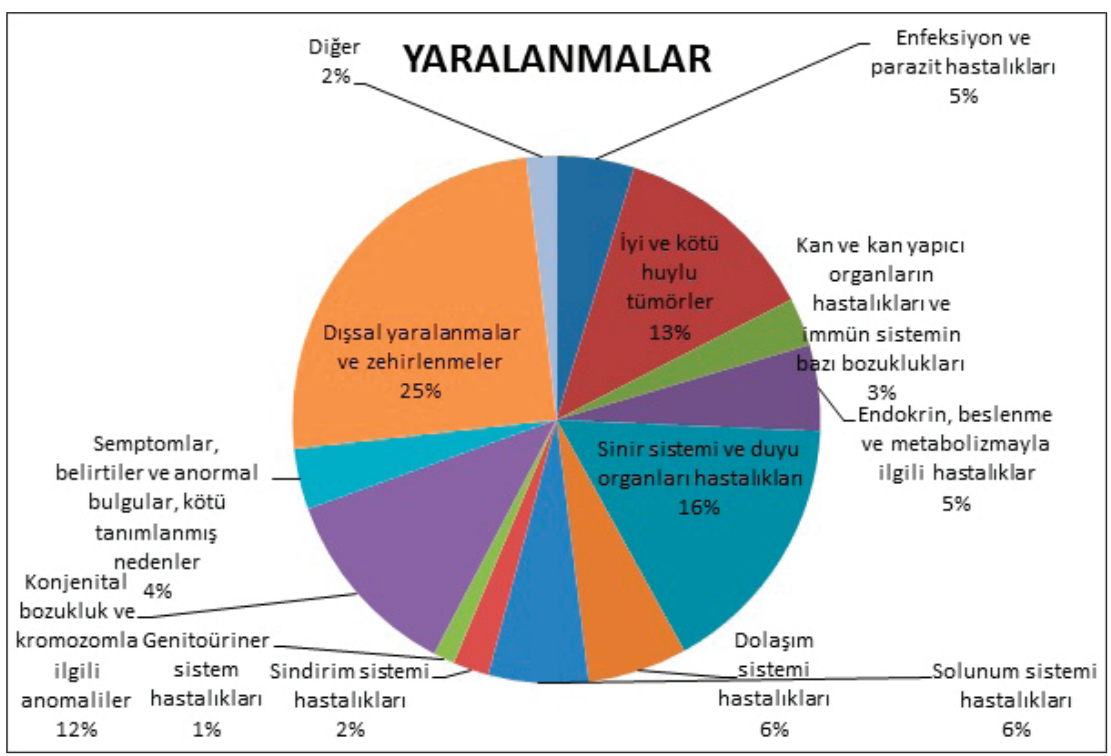

Grafik 1. 1-14 yaş arası çocukların ölüm nedenleri (1) 
zarar görmesine ve hata yapmalarına engel olmaya daha fazla odaklanmakta (23) ve bu durum olumlu risk alma davranışlarının gerçekleştirilmesini tehdit etmektedir. Olumlu risk alma davranışlarında ebeveyn müdahalesi, çocukların özgüven gelişimine katkı sağlayan, mücadele gücünü arttıran, başladığı bir görevi tamamlama motivasyonuna katkı sağlayan risk alma davranışlarına ket vurabilmektedir.

Bu bağlamda önleme programlarının içeriklerinin güvenlik ve olumlu risk alma davranışlarını destekleyiciliği açısından dengelenmesi ve bu programların uygulanacağı odak grupların detaylı bir şekilde tanımlanması önem kazanmaktadır. Yukarıda vurgulanan faktörlerin birbiri ile etkileşiminin çocukların yaralanma riski davranışlarında etkili olup olmadığının sınandığı araştırmalar, önleme programlarının odak gruplarının daraltılması ve programların detaylandırılması açısından önemli bir yol gösterici olacaktır. Bu doğrultuda bu çalışmada 4-5 yaş çocuklarının yaralanma riski davranışlarının cinsiyet, yaralanma tipi ve bağlamı etkileşimi açısından incelenmesi amaçlanmıştır. Bu amaca paralel olarak çalışmanın cevap aradığı araştırma soruları şunlardır:

1. Yaralanma Davranışı Kontrol Listesi, 3-6 yaş çocukları için geçerli ve güvenilir bir ölçme aracı mıdır?

2. Cinsiyet yaralanma riski davranışını etkiler mi?

3. Yaralanma bağlamı yaralanma riski davranışını etkiler mi?

4. Yaralanma tipi, yaralanma riski davranışını etkiler mi?

5. Cinsiyet ve yaralanma bağlamı etkileşimi yaralanma riski davranışını yorduyor mu?

6. Cinsiyet ve yaralanma tipi etkileşimi yaralanma riski davranışını yorduyor mu?

7. Yaralanma tipi ve yaralanma bağlamı etkileşimi yaralanma riski davranışını yorduyor mu?

\section{Gereç ve yöntem}

\section{Araştırmanın modeli}

Araştırma iki aşamada gerçekleştirilmiştir. İlk aşama Yaralanma Davranışı Kontrol Listesi (YDKL)'nin geçerlik ve güvenirlik aşaması, ikinci aşama ise çocukların yaralanma riski davranışlarının cinsiyet, yaralanma tipi ve bağlamı açısından incelenmesidir. Araştırmanın ilk aşamasında betimsel araştırma modeli, ikinci aşamada ise genel tarama modellerinden ilişkisel tarama modeli kullanılmıştır.

\section{Katılımcılar}

Çalışmaya 2016-2017 eğitim öğretim yılı bahar döneminde yaşları 36-71 ay arasında olan, 631 çocuk (40 çocuk pilot çalışma+ 493 çocuk geçerlik ve güvenirlik çalışması, 98 çocuk ilişkisel tarama) ve bu çocukların anneleri katılmıştır. Araştırmanın örneklemi, olasılık dışı örnekleme stratejilerinden eğitim araştırmalarında en yaygın kullanılan yöntemlerden biri olan (24) "uygun örnekleme yöntemi" doğrultusunda belirlenmiştir. YDKL'nin geçerlik ve güvenirlik çalışması için; açımlayıcı faktör analizi 280 çocuğa ait veri üzerinden gerçekleştirilirken, doğrulayıc faktör analizi ise 213 çocuğa $(\bar{x}=55.13$; SS $=9.38)$ ait veri üzerinden gerçekleştirilmiştir. Geçerlik ve güvenirlik çalışmasına dahil edilen çocukların 250'si kız, 243'ü ise erkek çocuktur. Bütün çocuklar iki ebeveyne sahiptir. Bu aşamaya ait veriler, 24 anaokulu ve ilkokula bağlı okul öncesi eğitim sınıflarından toplanmıştır (Toplam 6 il; İstanbul, Muş, Sakarya, Şanlıurfa, Trabzon, Van). Araştırmanın ikinci aşamasına dahil olan 98 çocuğun yaşları 43-65 ay aralığında (ay ortalaması $=57.88$ ) olup çocukların $49^{\prime} \mathrm{u}$ kız, 49'u ise erkek çocuktur. İlgili kontrol listesi çocukların anneleri tarafından doldurulmuştur ve tüm anneler araştırmaya gönüllü olarak dahil olmuştur. Bu aşamaya ait veriler ise Sakarya ve Trabzon illerindeki 8 anaokulu ve ilkokula bağlı okul öncesi eğitim sınıflarından toplanmıştır.

\section{Veri toplama araci}

Yaralanma Riski Davranışı: Çocukların yaralanma riski davranışlarını belirlemek için Speltz, Gonzales, Sulzbacher, ve Quan tarafından 1989 yılında geliştirilmiş olan YDKL kullanılmıştır (25). İlgili ölçme aracı 24 maddeden oluşan bir kontrol listesidir. Özgün araştırmada, $5^{\prime}$ li likert $(0=H i c ̧$ ile 4=Çok Sık) yapısına sahip olan kontrol listesinin, orta sınıf ailelerden oluşan örneklem için, iç tutarlıı̆̆ .88, test- tekrar test korelasyonu ise .81 olarak hesaplanmıştır. YDKL'nden elde edilen yüksek puanlar, çocukların daha fazla yaralanma riski olan davranışlar sergilediklerini ifade etmektedir.

\section{Prosedür}

YDKL'nin Türkçe uyarlamasını gerçekleştirmek amacıyla M.L. Speltz ile iletişime geçilmiş ve gerekli izin alınmıştır. Ölçeğin çeviri sürecinde TRAPD* modeli (Çeviri, İnceleme, Karar Verme, Ön Uygulama ve Belgeleme) kullanılmıştır (26). Illk aşama olan çeviri aşaması için, özgün formda yer alan maddeler her iki dile hakim olan 3 bağımsız çevirmene gönderilmiştir. Ardından araştırmacılar tarafından elde edilen çeviri metinleri her bir madde açısından incelemiş ve hedef dil için uygun olan ifadeler kararlaştırımıştır. Bu aşamada orijinal ölçekte yer alan iki madde, iki farklı eylemi içerdiği için araştırmacılar tarafından ayrı birer madde olarak ayrılmıştır. Bu maddeler 10. madde "Arabada emniyet kemeri kullanmayı ya da koltukta oturmayı reddeder" ifadesi; "Arabada emniyet kemeri kullanmayı reddeder" ile "Arabada koltukta oturmayı reddeder" şeklinde, 13. madde

*TRAPD (Translation, Review, Adjudication, Pretesting and

Documentation) 
"Pencereden düşer ve merdivenden yuvarlanır" ifadesi ise; "Pencereden düşer" ile "Merdivenlerden yuvarlanır" şeklinde ayrı birer madde olarak ayrılmıştır. Ardından karar aşaması olan üçüncü aşamada bir önceki aşamada uzlaşma sağlanan ifadeler alan uzmanlarından oluşan 5 akademisyene iletilmiştir. Alan uzmanlarının görüşlerinin elde edilmesinin ardından, ön uygulama aşamasına geçilmiş ve ilgili form 40 çocuk için anneleri tarafından doldurulmuştur. Ön uygulama sonucunda maddelerin anlaşılır olduğu sonucuna ulaşılmıştır. Araştırmanın ilk aşaması için gönüllü olan anneler 493 çocuk için ilgili ölçeği doldurmuştur. Daha sonra son aşama olan belgeleme aşamasına geçilmiştir. YDKL'ne ilişkin Türkçe maddeler Ek 1'de sunulmuştur.

Ölçeğin geçerlik ve güvenirlik çalışmasının ardından, çaIışmanın ikinci aşaması için veriler her okulda eğitim akış düzenini etkilemeyecek şekilde yaklaşık 20 dakikalık sürelerde gerçekleştirilmiştir. Araştırmacılar okul öncesi eğitim sınıflarının günlük eğitim akışı içerisindeki sanat etkinlikleri sırasında çocuklarla birlikte zaman geçirmişlerdir. Okul öncesi eğitim sınıflarında çocukların birbirleriyle olan etkileşimlerini en aza indirgemek için oturma düzeni yeniden düzenlenmiş̧ir. Ardından çocuklara "Yaralanmış bir çocuk çizer misin?" sorusu sorulmuş ve çocukların çizimlerini istedikleri şekilde (kuru boya, pastel boya vb.) yapabilecekleri söylenmiştir. Çocuklar çizimlerini tamamladıktan sonra, araştırmacılar çocuklardan çizimlerini anlatmalarını istemiş ve "Bu çocuk nasıl bir çocuk?, Kız mı erkek mi?, Kaç yaşında?, Neresi yaralanmış? Ne yaparken ve nerede yaralanmış?" soruları yöneltilmiştir. Çocukların çizimlerine ilişkin açıklamaları ses kayıt cihazı ile kayıt altına alınmıştır. Aynı zamanda ilgili form çizim yapan 98 çocuk için anneleri tarafından doldurulmuştur.

\section{Verilerin analizi}

Verilerin analizi için ilk aşamada ölçeğin geçerlik ve güvenirlik çalışması gerçekleştirilmiştir. YDKL'nin ölçmeyi amaçladığı yapıyı ölçüp ölçmediğini test etmek için (geçerlik için) doğrulayıcı faktör analizi (DFA) gerçekleştirilmiştir. Güvenirlik çalışması için ise iç-tutarlılık güvenirliği (Cronbach Alpha katsayısı) ve madde-toplam korelasyonları incelenmiştir. Çocuklarla yapılan görüşmede elde edilen ham veriler (çizimler ve ses kayıtları) yaralanma tipi için; düşme ( $\mathrm{N}=62)$ ve diğer ( $\mathrm{N}=36)$ olarak iki kategoride, yaralanma bağlamı için; sokak $(\mathrm{N}=33)$, park $(\mathrm{N}=34)$ ve diğer ( $(\mathrm{N}=31)$ olmak üzere 3 kategoride kodlanmıştır. Bunun yanı sıra çocuklarının yaralanma riski davranışlarının cinsiyet, yaralanma tipi ve bağlamı açısından incelenmesi amacıyla verilerin analizi için faktöriyel varyans analizi** kullanılmıştır.

\footnotetext{
**2 (cinsiyet), 2 (yaralanma tipi), 3 (yaralanma bağlamı) farklı ikililer
} halinde sınanamıştır.
EK 1. Yaralanma davranışı kontrol listesi

\begin{tabular}{ccccc}
0 & 1 & 2 & 3 & 4 \\
\hline Hiç & $\begin{array}{c}\text { Çok Nadir } \\
\text { (bir ya da iki kere) }\end{array}$ & $\begin{array}{c}\text { Bazen } \\
\text { (ayda bir) }\end{array}$ & $\begin{array}{c}\text { Oldukça Sık } \\
\text { (haftada bir) }\end{array}$ & $\begin{array}{c}\text { Çok Sık } \\
\text { (haftada birden fazla) }\end{array}$
\end{tabular}

\begin{tabular}{|c|l|l|l|l|l|l|}
\hline 1. & Caddeye fırlar. & 0 & 1 & 2 & 3 & 4 \\
\hline 2. & Mobilya ya da diğer eşyalardan atlar. & 0 & 1 & 2 & 3 & 4 \\
\hline 3. & Merdivenlerden atlar. & 0 & 1 & 2 & 3 & 4 \\
\hline 4. & Güvenli olmayan alanlarda bisiklet sürer. & 0 & 1 & 2 & 3 & 4 \\
\hline 5. & Bir şeylere (duvar, ağaç, eşya gibi) vurur ya da çarpar. & 0 & 1 & 2 & 3 & 4 \\
\hline 6. & Düşer. & 0 & 1 & 2 & 3 & 4 \\
\hline 7. & Ateşle oynar. & 0 & 1 & 2 & 3 & 4 \\
\hline 8. & $\begin{array}{l}\text { Parmaklarını ya da nesneleri elektronik aletlere ya da } \\
\text { prizlere sokar. }\end{array}$ & 0 & 1 & 2 & 3 & 4 \\
\hline 9. & İzin almadan evden çıkar. & 0 & 1 & 2 & 3 & 4 \\
\hline 10. & Arabada koltukta oturmayı reddeder. & 0 & 1 & 2 & 3 & 4 \\
\hline 11. & Arabada emniyet kemeri kullanmayı reddeder. & 0 & 1 & 2 & 3 & 4 \\
\hline 12. & Keskin/sivri nesnelerle oynar. & 0 & 1 & 2 & 3 & 4 \\
\hline 13. & Mobilyaları ya da ağır nesneleri çeker/devirir. & 0 & 1 & 2 & 3 & 4 \\
\hline 14. & Merdivenlerden yuvarlanır. & 0 & 1 & 2 & 3 & 4 \\
\hline 15. & $\begin{array}{l}\text { Cisimleri ya da yiyecek olmayan maddeleri } \\
\text { ağzına sokar. }\end{array}$ & 0 & 1 & 2 & 3 & 4 \\
\hline 16. & $\begin{array}{l}\text { Oyun sırasında vücudunda çizik, sıyrık, morluklar } \\
\text { oluşur. }\end{array}$ & 0 & 1 & 2 & 3 & 4 \\
\hline 17. & Oyun parkında "riskli olsa bile bir şeyleri dener". & 0 & 1 & 2 & 3 & 4 \\
\hline 18. & Mobilya ya da dolapların üstüne tırmanmaya çalışır. & 0 & 1 & 2 & 3 & 4 \\
\hline 19. & Sandalyede ayağa kalkar. & 0 & 1 & 2 & 3 & 4 \\
\hline 20. & İzin verilmeyen yasak yerleri araştııı veya inceler. & 0 & 1 & 2 & 3 & 4 \\
\hline 21. & Tehlikeli cisimlerin içine girer. & 0 & 1 & 2 & 3 & 4 \\
\hline 22. & $\begin{array}{l}\text { Çevredeki risklere dikkat etmeden ya da aldııı̧̧ } \\
\text { etmeden oynar. }\end{array}$ & 0 & 1 & 2 & 3 & 4 \\
\hline 23. & Sıcak nesnelere temas eder. & 0 & 1 & 2 & 3 & 4 \\
\hline 24. & $\begin{array}{l}\text { Su tehdidi (havuz, göl, baraj gibi) olan yerlerde ya da } \\
\text { çevresinde dikkatsizce davranır. }\end{array}$ & 0 & 1 & 2 & 3 & 4 \\
\hline 25. & Tanımadığı hayvanlara yaklaşır ve/veya onları & & & & & \\
\hline
\end{tabular}

\section{Bulgular}

\section{Betimleyici istatistiğe ilişkin bulgular}

Ait 26 (24+2 madde) maddelik yapının doğrulanıp doğrulanmadığını değerlendirmek amacıyla DFA uygulanmıştır. Uygulanan ilk DFA'da istatistiksel olarak anlamlı olmayan $t$ değerine sahip maddeler ile maddelerin hata varyansları incelenmiştir. Yapılan incelemeye göre tüm maddelerin $t$ değerlerinin anlamlı olduğu ancak \#14'ün hata varyansının yüksek olduğu tespit edilmiştir. Bu nedenle \#14 analiz dışı bırakılmıştır. YDKL'ne ait 25 maddelik Path diagramı Grafik 2'de yer almaktadır. Uyum indeksleri $X^{2}=637.73 \cdot X^{2 /}$ 


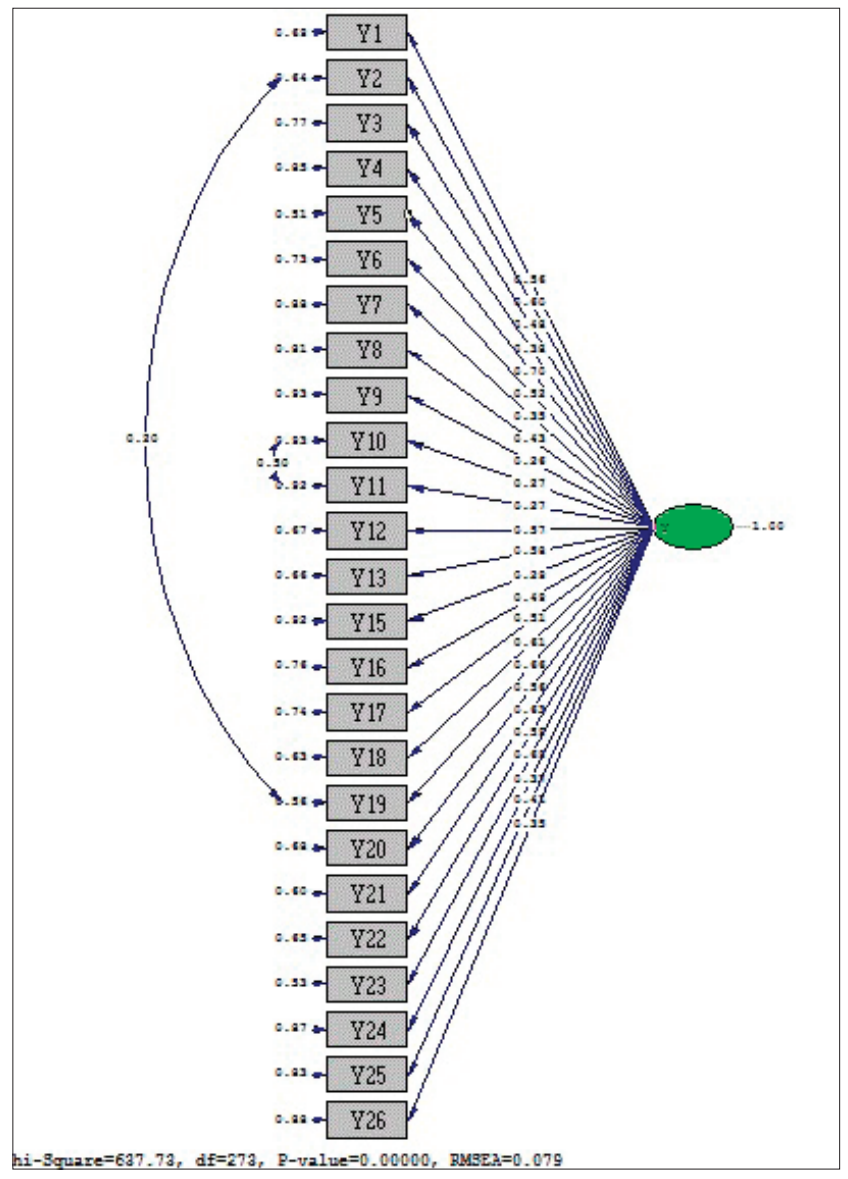

Grafik 2. YDKL'ne ilişkin path diyagramı

$\mathrm{sd}=$ 2.34. $\mathrm{RMSEA}=0.079 . \mathrm{CFI}=0.92 . \mathrm{NNF}=0.91$ ve $\mid \mathrm{FI}=0.92$ olarak bulunmuştur (Tablo 1). Bu ölçeğin faktöryel yapısını gösteren modelin gözlenen değişkenleriyle faktörleri arasındaki ilişkiyi gösteren katsayılar incelendiğinde, tüm katsayıların iyi düzeyde olduğu sonucuna varılmıştır. DFA ile hesaplanan uyum istatistikleri dikkate alındığında, ölçeğin daha önce belirlenen yapısının toplanan verilerle genel olarak uyum sağladığına karar verilmiştir.

\section{Güvenirlik}

Kontrol listesinin güvenirliği için YDKL'ne ait elde edilen regresyon katsayılarının ve $t$ değerlerinin anlamlı olduğu belirlenmiştir (Ek 2). YDKL'nin toplam puanına ilișkin Cronbach alfa katsayısı .89 olarak belirlenmiştir. Madde toplam analizi sonuçlarına göre ise YDKL'de yer alan herhangi bir maddenin çıkartılması cronbach alfa değerini daha fazla yükseltemeyeceğinden madde çıkartılması gereği görülmemiştir (Ek 3).

\section{Iliş̧kisel taramaya ilişkin bulgular}

Çalışmanın ikinci aşamasında çocuklardan yaralanmış bir çocuk çizmeleri istenmiştir. Çocukların çizimlerine ait örnekler Resim 1-4'de yer almaktadır.
Tablo 1. YDKL'nin tek faktörlü model için uyum indeksleri

\begin{tabular}{lc} 
Uyum Indeksleri & Tek Faktörlü Model \\
\hline x2/df & 2.34 \\
RMSEA & 0.079 \\
CFI & 0.92 \\
NNFI & 0.91 \\
IFI & 0.92
\end{tabular}

\section{EK 2. YDKL'ne ait regresyon ve t değerleri}

\begin{tabular}{lccccc} 
Maddeler & $\begin{array}{c}\text { Regresyon } \\
\text { değerleri }\end{array}$ & $\begin{array}{c}\boldsymbol{t} \\
\text { değerleri }\end{array}$ & Maddeler & $\begin{array}{c}\text { Regresyon } \\
\text { değerleri }\end{array}$ & $\begin{array}{c}\boldsymbol{t} \\
\text { değerleri }\end{array}$ \\
\hline Y1 & 0.56 & 8.42 & $\mathrm{Y} 15$ & 0.29 & 4.11 \\
Y2 & 0.60 & 9.16 & $\mathrm{Y} 16$ & 0.49 & 7.31 \\
Y3 & 0.48 & 7.16 & $\mathrm{Y} 17$ & 0.51 & 7.62 \\
Y4 & 0.38 & 5.53 & $\mathrm{Y} 18$ & 0.61 & 9.45 \\
Y5 & 0.70 & 11.30 & $\mathrm{Y} 19$ & 0.86 & 10.48 \\
Y6 & 0.52 & 7.77 & $\mathrm{Y} 20$ & 0.56 & 8.51 \\
Y7 & 0.35 & 4.94 & $\mathrm{Y} 21$ & 0.63 & 9.84 \\
Y8 & 0.43 & 6.28 & $\mathrm{Y} 22$ & 0.59 & 9.05 \\
Y9 & 0.26 & 3.67 & $\mathrm{Y} 23$ & 0.69 & 10.95 \\
Y10 & 0.27 & 3.79 & $\mathrm{Y} 24$ & 0.37 & 5.24 \\
Y11 & 0.27 & 3.87 & $\mathrm{Y} 25$ & 0.41 & 5.94 \\
Y12 & 0.57 & 8.74 & $\mathrm{Y} 26$ & 0.35 & 4.97 \\
Y13 & 0.58 & 8.90 & & &
\end{tabular}

EK 3. YDKL'ne ait maddelere ilişkin Cronbach Alpha değerleri

\begin{tabular}{|c|c|c|c|c|c|}
\hline Maddeler & $\begin{array}{c}\text { Madde } \\
\text { Toplam } \\
\text { Korelasyonu }\end{array}$ & $\begin{array}{c}\text { Madde } \\
\text { silindiğinde } \\
\text { Cronbach } \\
\text { Alpha Değeri }\end{array}$ & Maddeler & $\begin{array}{c}\text { Madde } \\
\text { Toplam } \\
\text { Korelasyonu }\end{array}$ & $\begin{array}{c}\text { Madde } \\
\text { silindiğinde } \\
\text { Cronbach } \\
\text { Alpha Değeri }\end{array}$ \\
\hline Y1 & .526 & .879 & Y15 & .451 & .881 \\
\hline Y2 & .597 & .876 & Y16 & .479 & .880 \\
\hline Y3 & .466 & .880 & Y17 & .565 & .877 \\
\hline Y4 & .359 & .883 & Y18 & .643 & .875 \\
\hline Y5 & .643 & .875 & Y19 & .552 & .878 \\
\hline Y6 & .461 & .880 & Y20 & .595 & .877 \\
\hline Y7 & .327 & .884 & Y21 & .520 & .880 \\
\hline Y8 & .389 & .883 & Y22 & .626 & .876 \\
\hline Y9 & .239 & .885 & Y23 & .340 & .883 \\
\hline Y10 & .312 & .886 & Y24 & .380 & .882 \\
\hline Y11 & .321 & .886 & Y25 & .329 & .884 \\
\hline Y12 & .544 & .878 & Y26 & .281 & .885 \\
\hline Y13 & .546 & .878 & & & \\
\hline
\end{tabular}




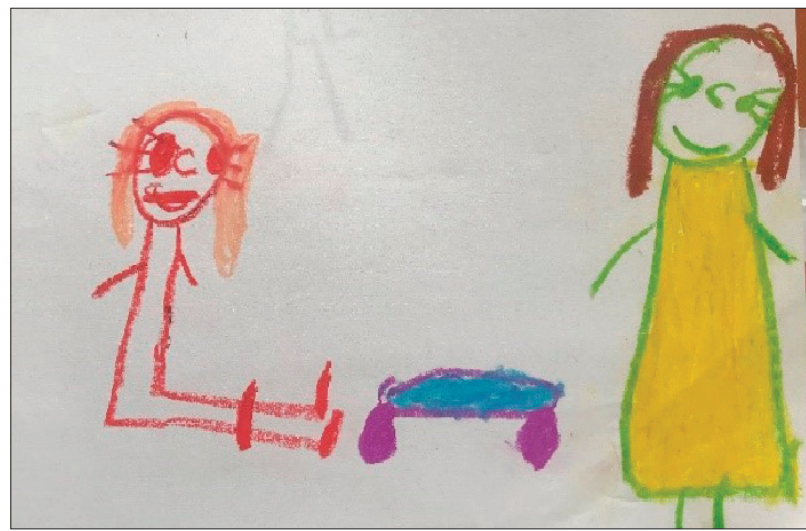

Şekil 1. C. A. (Kız)- 58 ay «Kaykaydan kayarken taşa taklıp düşmüş»

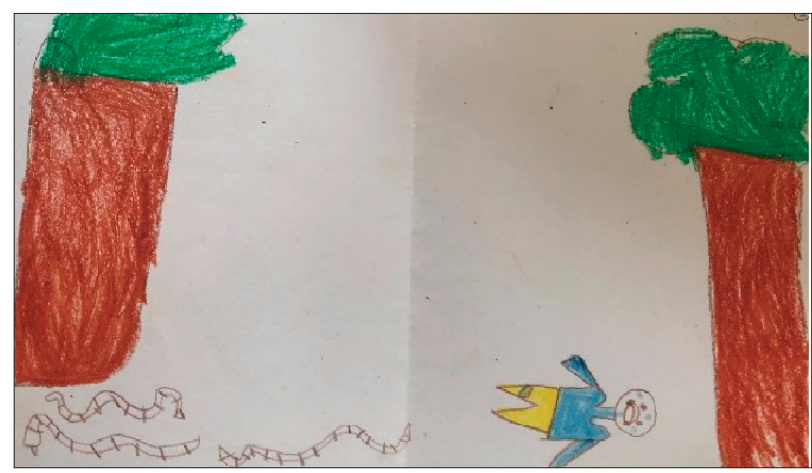

Şekil 2. D. E. (Kız)- 55 ay «Ormanda yürürken yılanlar onun bacağını ısırmış ve ağlamış»

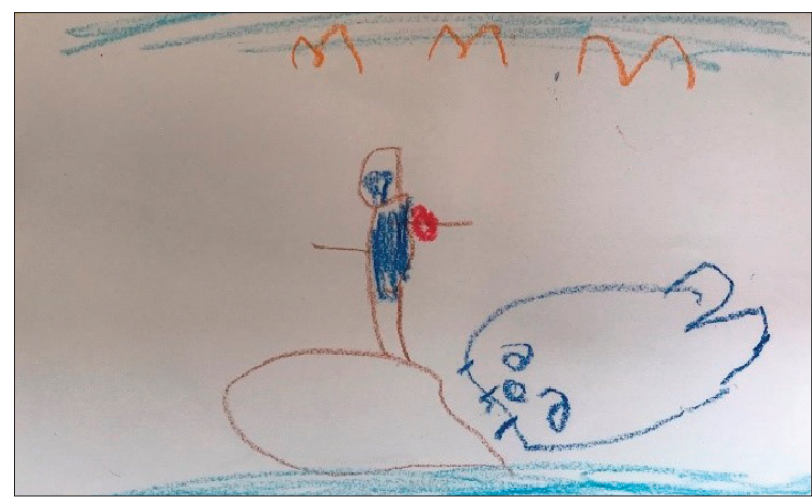

Şekil 3. B. K. (Erkek)- 54 ay «Köpekbalığı ısırmış. Misinayla balık tutarken köpekbalığı atlamış kolunu ısırmış»

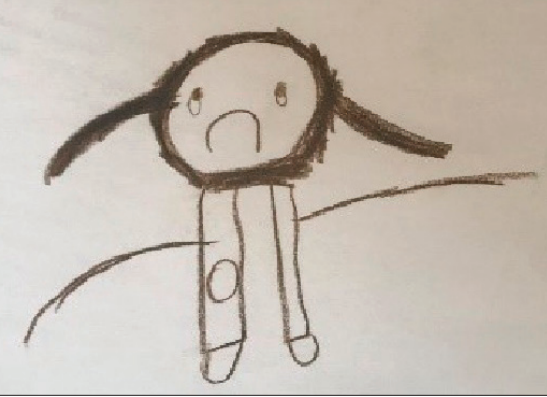

Şekil 4. B. D. (Kız)- 49 ay «Koşarken düşmüş»
Çocuklarının yaralanma riski davranışlarının cinsiyet, yaralanma tipi ve bağlamı açısından incelenmesi amacıyla verilerin analizi için faktöriyel varyans analizi kullanılmıştır (Tablo 2).

\section{Tablo 2. Faktöriyel varyans analizi}

\begin{tabular}{|c|c|c|c|c|c|c|}
\hline $\begin{array}{l}\text { Varyansın } \\
\text { Kaynağı }\end{array}$ & $\begin{array}{l}\text { Kareler } \\
\text { Toplamı }\end{array}$ & $\begin{array}{c}\text { Serbestlik } \\
\text { Derecesi }\end{array}$ & $\begin{array}{c}\text { Kareler } \\
\text { Ortalaması }\end{array}$ & $F$ & $p$ & $\eta^{2}$ \\
\hline Cinsiyet & 1527.29 & 1 & 1527.29 & 10.95 & .001 & .113 \\
\hline Yaralanma Tipi & 21.95 & 1 & 21.95 & .16 & .693 & .002 \\
\hline $\begin{array}{l}\text { Yaralanma } \\
\text { Bağlamı }\end{array}$ & 933.90 & 2 & 466.95 & 3.35 & .040 & .072 \\
\hline $\begin{array}{l}\text { Cinsiyet* }^{\star} \\
\text { Yaralanma Tipi }\end{array}$ & 891.94 & 1 & 891.94 & 6.39 & .013 & .069 \\
\hline $\begin{array}{l}\text { Cinsiyet* } \\
\text { Yaralanma } \\
\text { Bağlamı }\end{array}$ & 242.80 & 2 & 121.40 & .87 & .422 & .020 \\
\hline $\begin{array}{l}\text { Yaralanma Tipi } \\
\text { *Yaralanma } \\
\text { Bağlamı }\end{array}$ & 235.26 & 2 & 117.63 & .84 & .434 & .019 \\
\hline
\end{tabular}

Faktöriyel varyans analizi (ANOVA), cinsiyet $\left(F_{\left(1^{\prime} 86\right)}=10.95\right.$, $\mathrm{p}<.05)$ ve yaralanma bağlamı $\left(F_{(1,86)}=3.35, p<.05\right)$ değişkenlerinin yaralanma riski davranışlarında etkisinin olduğunu ortaya koymuştur. Yaralanma bağlamının sokak olduğunu vurgulayan çocukların yaralanma puanlarının $(M=21.06, S D=17.56)$, park $(M=13.41, S S=7.28)$ ve diğer yerlerde $(M=19.93, S S=11.17)$ yaralandığını belirten çocuklara göre daha yüksek olduğu saptanmıştır. Bu bulguların pratikte de anlamlı olup olmadığı etki büyüklüğü incelenerek değerlendirilmiştir. Cinsiyet değişkeni için hesaplanan eta-kare değeri $\left(\eta^{2}=.113\right)$ cinsiyetin yaralanma riski davranışı üzerindeki etki büyüklüğünün geniş olduğunu gösterirken, yaralanma bağlamı değişkeni için hesaplanan eta-kare değeri $\left(\eta^{2}=.072\right)$ bu değişken için etki büyüklüğünün orta düzeyde olduğunu göstermektedir. Ayrıca, çocukların yaralanma riski davranışı puanlarının, cinsiyet ve yaralanma tipi değişkenlerinin etkileşimine göre farklılaştığı $\left(F_{\left(1^{\prime} 86\right)}=6.39, p<.05\right)$ ve bu iki değişkenin etki büyüklüğü değerinin $\left(\eta^{2}=.069\right)$ orta düzeyde olduğu tespit edilmiştir. Bunun yanı sıra Tablo 2'ye göre yaralanma bağlamı (bu anlamda sokak) tek başına anlamIı bir değişken iken, yaralanma tipi ve yaralanma bağlamı değişkenlerinin etkileşim etkisi, çocukların yaralanma riski davranışlarında farklılık yaratmamaktadır $\left(\mathrm{F}_{\left(1^{\prime} 86\right)}=.84, \mathrm{p}\right.$ $=.43$ ). Bir diğer ifade ile sokak, park ya da diğer alanlarda düşme ve/ya diğer tipte yaralanmalar yaşayan çocukların yaralanma riski davranışlarında anlamlı bir fark olmadığını söylemek mümkündür. 


\section{Tartışma}

Çocukluk çağı yaralanmaları, uzun yıllardır farklı disiplinlerden araştırmacıların ilgi alanı olmuştur. Günümüze kadar, çocukluk çağı yaralanmaları konusunda en kapsamlı katkıyı hiç kuşkusuz sağlık bilimleri alanında görev yapan araştırmacılar gerçekleştirmiştir. Bu katkı çocukluk çağı yaralanmalarının tanılanması, bu yaralanmalara etki eden faktörlerin tespit edilmesi ve güvenlik önlemlerinin belirlenmesi açısından oldukça değerlidir. Son 20 yılda sağlık bilimlerinin yanı sıra psikoloji ve eğitim bilimleri alanlarında görev yapan araştırmacıların da, çocuk yaralanmalarını çocuğun cinsiyeti, yaşı, mizacı (5), kardeş sayısı (7) gibi psikolojik değişkenler üzerinden analiz etme çabalarında artış gözlemlenmektedir. Bu artış çocuk yaralanmalarının gelişimsel ve psikolojik çerçevesini ortaya koyması ve çocuk yaralanmalarına geniş bir perspektiften bakılmasına yardımcı olması bakımından oldukça anlamlıdır. Bu araştırma da, okul öncesi dönem çocuklarının yaralanma riski davranışlarında cinsiyet, yaralanma tipi ve yaralanma bağlamının etkisini ve bu psikolojik değişkenlerin birbirleri ile etkileşim etkisini araştırmayı hedeflemiştir. Araştırmada öncelikli olarak Speltz, Gonzales, Sulzbacher ve Quan (1990) tarafından geliştirilen YDKL'nin geçerlik ve güvenirlik çalışması gerçekleştirilmiştir. 2008 yılında YDKL'nin Türkçe'ye uyarlaması Uysal, Ergül ve Ardahan tarafından gerçekleştirilmiş ve içtutarlıık katsayısı .87 olarak saptanmıştır (27). Bu araştırmada ise YDKL'nin yapısının doğrulanıp doğrulanmadığı DFA ile analiz edilmiş ve DFA sonucunda bir maddenin analiz dışı bırakılması gerekliliği ortaya çıkmış ve bu maddenin analiz dışı bırakılması ile içtutarlılık katsayısının .88 olduğu tespit edilmiştir. Analizler sonucunda 25 maddelik YDKL'nin okul öncesi dönem çocuklarının yaralanma riski davranışlarını geçerli ve güvenilir bir şekilde ölçtüğü saptanmıştır.

Çocukların yaralanma riski davranışlarını geçerli ve güvenilir biçimde ölçen bir ölçme aracına ulaşılmasının ardından çeşitli psikolojik değişkenlerle etkileşimi incelenmiştir. Alanyazında çocukların yaralanma riski davranışlarında cinsiyet faktörünün etkisi çok net bir şekilde ortaya konmuştur (2). Bu araştırmada da elde edilen bulgulardan biri, cinsiyetin ve yaralanma bağlamının (sokak, park ve diğer), çocukların yaralanma riski davranışlarında belirleyici olduğu yönündedir. Çocuğun cinsiyeti, yaralanma riski davranışlarında etki değeri en yüksek değişken olarak saptanmıştır. Yaralanma risklerindeki cinsiyet farklılıkları 3-4 yaş öncesinde ve neredeyse her tür yaralanma türleri için gözlenmektedir $(28,29)$. Ancak bu kesinlik yaralanma bağlamı için literatürel anlamda henüz kanıtlanmamıştır. Çeşitli araştırmalar okul öncesi dönemdeki çocukların en sık yaralandıkları bağlamın ev olduğunu saptamıştır $(9,10)$. Bu araştırmada ise yaralanma bağlamının çocukların yaralanma riski davranışlarında anlamlı fark yarattığı, ancak sokakta yaralandığını ifade eden çocukların daha fazla yaralanma riski davranışları sergiledikleri saptanmıştır. Bu farklıığın kaynağının araştırmaların örneklem gruplarından kaynaklandığını düşünmek mümkündür. Bu araştırmanın örneklemini okul öncesi eğitim kurumlarına devam eden çocuklar oluşturmaktadır. Bombacı, Ülkü, Adıyeke, Kara ve Görgeç (2008)'in araştırmalarında ise örneklem grubunu sağlık hizmetlerine başvuran çocuklar oluşturmaktadır. Bu noktada evde gerçekleşen yaralanmalar ile sokakta gerçekleşen yaralanmalar sonrasında sağlık hizmetlerine başvurma oranlarına ilişkin detaylı bir araştırmaya ihtiyaç duyulduğu açıktır. Bunun dışında yaralanma bağlamının (bu anlamda sokağın), yaralanma riski davranışlarında belirleyici bir etkisinin olduğu bulgusu, çocuk yaralanmalarının önlenmesi konusunda geliştirilecek önleme programlarına sağlık bilimleri ve eğitim bilimleri uzmanlarının yanı sıra kentsel planlama uzmanlarının da dahil olması gerekliliğine vurgu yapmaktadır. Çünkü çocuklar sokağı bir oyun alanı olarak değerlendirmekte (30) ve çocukların yaralanma oranları sokağın yapısına göre değişkenlik gösterebilmektedir. Örneğin çift yönlü sokaklarda çocuk yayaların yaralanma oranları tek yön olan sokaklara oranla 2.5 kat daha fazla olduğu bilinmektedir (31). Yaralanma bağlamının etkisine karşın, yaralanma tipinin (düşme ve diğer yaralanmalar) tek başına çocukların yaralanma riski davranışlarında fark yaratmadığı saptanmıştır. Bir diğer ifade ile bir çocuğun düşerek, kesici-delici aletlerle, yanma vd. gibi yaralanmalar geçirmesi yaralanma riski davranışlarını üzerinde belirleyici bir etkiye sahip olmamaktadır.

Araştırma sonucunda elde edilen ilginç bulgulardan ikisi, cinsiyet-yaralanma tipi ve cinsiyet-yaralanma bağlamı etkileşimine ait bulgulardır: Cinsiyet tek başına anlamlı bir değişken iken, cinsiyet ve yaralanma bağlamı değişkenlerinin etkileşim etkisi, çocukların yaralanma riski davranışlarında farklılık yaratmamaktadır. Bir diğer ifade ile sokak, park ya da diğer alanlarda yaralanma yaşayan erkek ve/ya kız çocuklarının yaralanma riski davranışlarında anlamlı bir fark olmadığını söylemek mümkündür. Bu bulgu yapılan diğer araştırmalarda elde edilen bulgularla benzerlik göstermektedir. Örneğin çocukların sokakta karşıdan karşıya geçmesini inceleyen bir araştırmada (32) çocukların ne zaman geçileceğine karar verirken mesafe ipuçları kullandıkları ve bu durumun çocukların yaş ve cinsiyetine bağlı olarak farklılık yaratmadığı ortaya çıkmıştır. Bunun yanı sıra yaralanma tipi tek başına 
anlamlı bir değişken olmazken, cinsiyet ve yaralanma tipi değişkenlerinin etkileşim etkisi, çocukların yaralanma riski davranışlarında farklılık yaratmakta ve bu farkın etki büyüklüğü orta düzeydedir. Bir diğer ifade ile yaralanma riski davranışlarında düşme tipi yaralanmalar geçiren erkek çocukların, diğer gruplara göre anlamlı fark oluşturduğunu söylemek mümkündür. Bu bağlamda planlanan önleme programlarında düşme tipi yaralanmalar geçiren erkek çocuklara ve ailelerine öncelik verilmesinin istemsiz yaralanmalar üzerinde kapsamlı bir etkisinin olacağını söylemek mümkündür.

\section{Kaynaklar}

1. Türkiye İstatistik Kurumu [TÜIKK]. 2013-2014 Ölüm nedeni istatistikleri-Haber Bülteni. 2015; Sayı: 18622.

2. Andrade C, Cordovil R, Barreiros J. Injuries in preschool children: the hypothetical protector effect of minor injuries and risk factors for minor and medically attended injuries. International Journal of Injury Control and Safety Promotion, 2013; 20: 239-44. [CrossRef]

3. Granie MA. Gender stereotype conformity and age as determinants of preschoolers'injury-risk behaviors. Accident Analysis \& Prevention, 2010; 42: 726-33. [CrossRef]

4. Bijttebier P, Vertommen $\mathrm{H}$, Florentie K. Risk-taking behavior as a mediator of the relationship between children's temperament and injury liability. Psychology and Health, 2003; 18: 645-53. [CrossRef]

5. Schwebel DC. Temperamental risk factors for children's unintentional injury: The role of impulsivity and inhibitory control. Personality and Individual Differences, 2004; 37: 567-78. [CrossRef]

6. Rowe R, Maughan B. The role of risk-taking and errors in children's liability to unintentional injury. Accident Analysis \& Prevention, 2009; 41: 670-5. [CrossRef]

7. Morrongiello BA, Schell SL, Schmidt S. "Please keep an eye on your younger sister": sibling supervision and young children's risk of unintentional injury. Injury prevention, 2010; 16: 398-402. [CrossRef]

8. Nathens AB, Neff MJ, Goss CH, Maier RV, Rivara FP. Effect of an older sibling and birth interval on the risk of childhood injury. Injury Prevention, 2000; 6: 219-22. [CrossRef]

9. Bombacı H, Ülkü K, Adıyeke L, Kara S, Görgeç M. Çocuk yaralanmaları, nedenleri ve önlemler. Acta Orthop Traumatol Turc, 2008; 42, 166-73.

10. Thacker SB, Addiss DG, Goodman RA, Holloway BR, Spencer HC. Infectious diseases and injuries in child day care, 1992, JAMA, 268, 1720-26. [CrossRef]

11. Çelik ID, Baysal SU, Coşgun L, Taviloğlu K, Ünüvar E. (2008). Çocukluk çağı yaralanmalarında hazırlayııı nedenler. Türk Pediatri Arşivi, 43 84-8.

12. Ince T, Yalçın SS, Yurdakök K. Çocukluk çağında ciddi kaza sıklığı ve risk faktörleri. Çocuk Sağlığı ve Hastalıkları Dergisi, 2014; 57: 173-82.

13. Karatepe TU, Akış N. 0-6 yaş çocuklarda ev kazası geçirme sıklığı ve ilişkili faktörler. Uludağ Üniversitesi Tıp Fakültesi Dergisi, 2013; 39: 165-8.

14. Özkan S, Avşaroğulları L, Sözüer EM, İkizceli I, Taymuş E, Kılıç Ş. Okul öncesi çocukluk çağı yaralanmalarının özellikleri. Akademik Acil Tıp Dergisi, 2006; 4: 17-20.

15. Özmen D, Ergin D, Şen N, Çetinkaya A. 0-6 yaş grubu çocuğu olan annelerin ev kazalarına yönelik güvenlik önlemlerinin tanılanması. Sosyal Politika Çalışmaları Dergisi, 2007; 12: 13-20.

16. Tural Büyük E, Çavuşoğlu F, Teker E. Sıfır altı yaş arası çocuğu olan annelerin ev kazalarına yönelik güvenlik önlemlerinin tanılanması. Düzce Üniversitesi Sağlık Bilimleri Enstitüsü Dergisi, 2015; 5: 17-22.
Sonuç olarak, geçmiş yıllarda gerçekleştirilen çalışmalardan ve bu araştırmadan elde edilen bulgular, farklı disiplinlerde görev yapan ve çocukluk çağı yaralanmalarını önlemeyi hedefleyen araştırmacıların kapsamlı bir önleme çalışması gerçekleştirmesinin ancak disiplinlerarası çalışma çabaları ile mümkün olacağını göstermektedir. Bu disiplinlerarası önleme programında sağlık hizmetlerinde ve eğitim alanında görev yapan araştırmacı ve uygulayıclların yanı sıra kentsel planlama uzmanlarının da yer alması, ilgili önleme programlarının etkililiğini ve sürdürülebilirliğini arttıracaktır.

17. Yalaki Z, Taşar MA, Kara N, Dallar Y. Sosyoekonomik düzeyi düşük olan ailelerin ev kazaları hakkında bilgi düzeylerinin ölçülmesi. Akademik Acil Tıp Dergisi, 2010; 9: 129-33. [CrossRef]

18. Yılmaz Kurt F, Aytekin A. 0-6 yaş grubu çocuklarda ev kazaları. Sağlık Bilimleri ve Meslekleri Dergisi, 2015; 2: 22-32.

19. Potts R, Swisher L. Effects of televised safety models on children's risk taking and hazard identification. Journal of Pediatric Psychology, 1998; 23: 157-63. [CrossRef]

20. Roberts I, Kramer MS, Suissa S. Does home visiting prevent childhood injury? A systematic review of randomised controlled trials. British Medical Journal, 1996; 312: 29-33. [CrossRef]

21. Turan T, Altundağ DS, Yorgancı M, Yıldııım Z. 0-6 yaş grubu çocuklarda ev kazalarının önlenmesi. Ulus Travma Acil Cerrahi Dergisi, 2010; 16: 552-7.

22. Little H. Children's risk-taking behaviour: implications for early childhood policy and practice. International Journal of Early Years Education, 2006; 14: 141-54. s.142. [CrossRef]

23. Niehues AN, Bundy A, Broom A, Tranter P. Parents' perceptions of risk and the influence on children's everyday activities. Journal of Child and Family Studies, 2015; 24: 809-20. [CrossRef]

24. McMillan JH. Educational research: Fundamentals for the consumer. HarperCollins College Publishers, New York. 1996.

25. Speltz ML, Gonzales N, Sulzbacher S, Quan L. Assessment of injury risk in young children: A preliminary study of the Injury Behavior Checklist. Journal of Pediatric Psychology, 1990; 15: 373-83. [CrossRef]

26. Harkness JA. Questionnaire Translation. In Harkness, J. A., van de Vijver, F. J. R. and Mohler, P. P. (Eds.). Cross-Cultural Survey Methods. Hoboken: Wiley, 2003: pp. 35-56.

27. Uysal A, Ergül Ş, Ardahan M. Okul öncesi çocuklarda yaralanma riski. Ege Üniversitesi Hemşirelik Yüksekokulu Dergisi, 2008; 24: 105-14.

28. Canadian Institute of Child Health. The health of Canada's children: A $\mathrm{ClCH}$ profile (3rd ed.). Ottawa: Canadian Institute of Child Health. 2000.

29. Rivara FP, Bergman AB, LoGerfo JP, Weiss NS. Epidemiology of childhood injuries: II. Sex differences in injury rates. American Journal of Diseases of Children, 1982; 136: 502-6.

30. Menevşe EB, Küçükturan AG. Okul öncesi çocukların sokak algılarına ilişkin bir çalışma. 5. Uluslararası Okul Öncesi Eğitim Kongresi Özet Bildiri Kitapçı̆̆l; 2017 Ekim 18-21; Ankara, Türkiye; 2017. s. 375.

31. Wazana A, Rynard VL, Raina P, Krueger P, Chambers L. W. Are child pedestrians at increased risk of injury on one-way compared to twoway streets?. Can J Public Health, 2000; 91: 201-6. [CrossRef]

32. Morrongiello BA, Corbett $M$, Milanovic $M$, Beer J. Using a virtual environment to examine how children cross streets: Advancing our understanding of how injury risk arises. Journal of pediatric psychology, 2015; 41: 265-75. [CrossRef] 